\title{
Satellite Tracking of Post-nesting Green Sea Turtles (Chelonia mydas) From Ras Baridi, Red Sea
}

\section{OPEN ACCESS}

Edited by:

Graeme Clive Hays,

Deakin University, Australia

Reviewed by:

Gail Schofield,

Queen Mary University of London,

United Kingdom

Kristen Marie Hart,

United States Geological Survey

(USGS), United States

Nicole Esteban,

Swansea University, United Kingdom

Paolo Luschi,

University of Pisa, Italy

*Correspondence:

Ahmed M. Al-Mansi

aalmansi@mewa.gov.sa;

mansi911@hotmail.com

Specialty section:

This article was submitted to

Marine Megafauna,

a section of the journal

Frontiers in Marine Science

Received: 14 August 2021 Accepted: 08 November 2021 Published: 30 November 2021

Citation:

Al-Mansi AM, Sambas AZ, Abukaboos BA, Al Zahrani AH, Abdulaziz AS, Almasabi AA,

Alkreda RS and Miller J (2021)

Satellite Tracking of Post-nesting Green Sea Turtles (Chelonia mydas)

From Ras Baridi, Red Sea.

Front. Mar. Sci. 8:758592.

doi: 10.3389/fmars.2021.758592

\author{
Ahmed M. Al-Mansi' ${ }^{*}$, Anas Z. Sambas ${ }^{2}$, Baleegh A. Abukaboos², \\ Ahmed H. Al Zahrani' ${ }^{2}$ Ahmed S. Abdulaziz ${ }^{2}$, Ali A. Almasabi2, Raed S. Alkreda ${ }^{2}$ and \\ Jeff Miller ${ }^{3}$
}

${ }^{1}$ Ministry of Environment, Water and Agriculture, Riyadh, Saudi Arabia, ${ }^{2}$ National Center for Wildlife, Riyadh, Saudi Arabia,

${ }^{3}$ Biological Research and Education Consultants, Missoula, MT, United States

Identifying migratory pathways and linking nesting sites to foraging areas is essential for effective conservation management of migratory species, such as marine turtles. Postnesting marine turtles disperse from their nesting sites to multiple foraging areas located from a few to hundreds of kilometers away. Over a six-year period 16 female green turtles (Chelonia mydas) were equipped with satellite transmitters between October and December of five nesting seasons to determine their migratory routes from their nesting area at five contiguous beaches at Ras Baridi, Saudi Arabia, to their foraging areas. All foraging areas for these turtles were located in shallow coastal areas or in shallow areas around offshore islands within the Red Sea basin. The majority $(n=12)$ migrated through the shallow $(<200 \mathrm{~m})$ water along the coastal margin to reach foraging areas located to the North $(n=4)$ and South $(n=12)$ of the nesting site. Four turtles crossed the deep trough of the Red Sea during their journeys. Ten of the 16 turtles migrated to foraging areas within the territorial waters of Saudi Arabia. The other six turtles migrated to foraging areas in Egypt $(n=4)$ and Eritrea $(n=2)$. These 16 turtles traveled between 130 and $1749 \mathrm{~km}$ from their nesting site to foraging areas located in the northern, middle and southern parts of the Red Sea. Because these turtles utilized foraging areas in at least three countries (Saudi Arabia, Egypt, and Eritrea) and one passed through the territorial waters of Sudan, conservation and management of green turtles in the Red Sea requires multinational cooperation to address anthropogenic threats in the region.

Keywords: satellite tracking, green turtle, Chelonia mydas, Red Sea, Ras Baridi

\section{INTRODUCTION}

The success of conservation efforts for animals that migrate between habitats when they reproduce (e.g., birds: Egevang et al., 2010; fish: Tamario et al., 2019; sea turtles: Russell et al., 2005) depends on understanding their population biology as well as the distribution of important habitats and the connections among these habitats in the context of threatening processes that may be encountered (Martin et al., 2007; Lascelles et al., 2014; Gajdzik et al., 2021). Because migrations for reproduction vary in length depending on the species and the distance between the habitats (Luschi, 2013; Lascelles et al., 2014; Dunn et al., 2019), the routes followed may cross international borders and, as a result, migrating animals may encounter different anthropogenic threats in different jurisdictions (López-Hoffman et al., 2017; Palacios-Abrantes et al., 2020; Gajdzik et al., 2021). 
Specific details concerning the distribution and use of important habitats and the connecting migratory routes are needed on an appropriate scale so that regional ecosystem management options can be coordinated and tailored to reduce threatening processes (Rees et al., 2016; Lagabrielle et al., 2018; Hernandez-Avila et al., 2020; Gajdzik et al., 2021). This is particularly important in a marginal sea such as the Red Sea, wherein the majority of the coastal margin is managed by six countries (two other countries border the Gulf of Aqaba) (PERSGA, 2006). The Regional Organization for the Conservation of the Environment of the Red Sea and Gulf of Aden (PERSGA) has a prominent role in coordinating the protection of the marine and coastal environments in the region, including developing guidelines for conservation of living marine resources (e.g., Hariri et al., 2002; PERSGA, 2007). However, the existing marine protected areas in the Red Sea do not seem to provide the level of protective conservation management needed by very mobile and migratory species (i.e., dugong, turtles, and sharks, Rouphael et al., 2015). At least part of this situation stems from the lack of information concerning the migratory routes and habitats used by these marine species in the region (Gajdzik et al., 2021). Understanding the connectivity among important habitats (i.e., foraging areas, nesting sites) and the routes used to connect them is essential to development of effective conservation practices (Bolker et al., 2007; Dunn et al., 2019).

Adult marine turtles are bi-directional migratory iteroparous species that spend the majority of their time in their foraging areas where they live and periodically prepare for reproduction (Miller, 1997; Plotkin, 2003). Reproducing female sea turtles migrate to breeding areas and specific nesting beaches where they oviposit several clutches of eggs at intervals of about 2 weeks, and then return to their foraging areas (Meylan et al., 1990; Miller, 1997; Godley et al., 2008). Marine turtles show high fidelity to both their nesting and foraging areas (Limpus et al., 1992; Pilcher et al., 2020; Shimada et al., 2020). During their reproductive migrations green turtles (Chelonia mydas) may utilize coastal and open water corridors (Pendoley et al., 2014; Stokes et al., 2015; Mettler et al., 2019) and/or pass through the territorial waters of one or more nations (Blanco et al., 2012; Rees et al., 2012, 2018; Hart et al., 2018; Pilcher et al., 2021a,b). They may transit areas used for artisanal and/or commercial fishing (Gladstone, 2002; PERSGA, 2003, 2004, 2006, 2007). Although fishing is regulated in every country that borders the Red Sea, the impact of bycatch on the turtle populations is poorly defined (PERSGA, 2003; Mancini et al., 2015).

In recent years, satellite tracking of marine turtle movements between their nesting sites and foraging areas has elucidated much of the previously unknown biology and habitat use (Godley et al., 2002, 2008; Luschi et al., 2003; Blumenthal et al., 2006; Hart et al., 2013, 2017; Luschi and Casale, 2014; Pilcher et al., 2014, 2021a,b; Rees et al., 2016; Ferreira et al., 2020), including bi-directional movements (Limpus and Limpus, 2001; Pilcher et al., 2020). It is now well established that post-nesting turtles which used a particular nesting location return to several different foraging areas (Luschi et al., 1996; Bjorndal et al., 2005; Blumenthal et al., 2006; Bolker et al., 2007; Bradshaw et al., 2017; Shimada et al., 2020). Conversely, turtles foraging in one general habitat disperse to several different nesting locations (i.e., mixed stock) (Limpus et al., 1992; Dethmers et al., 2010; Carreras et al., 2011; Jensen et al., 2013; Read et al., 2015; Dutton et al., 2018). In combination with other methods (e.g., genetics), satellite tracking of marine turtles can be used to better define the uniqueness of nesting populations and shared use of habitat (Godley et al., 2010; Hart et al., 2012, 2020; Bourjea et al., 2015; Jensen et al., 2019). In addition, satellite tracking of marine species has contributed to identifying important foraging areas (Pilcher et al., 2014; Stokes et al., 2015, 2019), threatening processes (Hays et al., 2003; Hart et al., 2018), and helped with development of conservation and management options (Hays et al., 2014, 2019, 2021; Pendoley et al., 2014; Hays and Hawkes, 2018).

However, a better understanding of the migration patterns of marine species is necessary to support conservation efforts and to identify potential areas of threatening processes in the Red Sea (Gajdzik et al., 2021), particularly for species that are globally or regionally at risk. Of the five species of sea turtles that occur in the Red Sea, at least infrequently (Mancini et al., 2015), the green turtle (Chelonia mydas) and the hawksbill (Eretmochelys imbricata) are regularly observed. The loggerhead (Caretta caretta), the olive-ridley (Lepidochelys olivacea), and the leatherback (Dermochelys coriacea) are less commonly seen (Ross and Barwani, 1982; Frazier et al., 1987; Pilcher et al., 2006; PERSGA, 2010; Mancini et al., 2015; Miller, 2020). In the northern Indian Ocean region, the herbivorous green turtle (Bjorndal, 1997; Stokes et al., 2019; Esteban et al., 2020) is classified as Vulnerable (Mancini et al., 2019) and is listed in Appendix 1 of the Convention on International trade of Endangered Species (CITES, 2021).

Although the information concerning the routes used by green turtles as they migrate between nesting sites and foraging areas in the Arabian region is increasing (Pilcher et al., 2020, 2021a,b) much remains to be determined. Currently, little is known about the connectivity between nesting sites and foraging areas for green turtles (Mancini et al., 2015, 2018; Pilcher et al., 2021b) or about foraging area inclusion in existing Marine Protected Areas (MPAs) in the Red Sea because a relatively low number of green turtles have been tracked to foraging areas (Rouphael et al., 2015; Gajdzik et al., 2021). In 2010 satellite transmitters were used to identify the migratory pathways of four green turtles that had nested at Zabargad Island (off shore of Egypt) (Attum et al., 2014). This study provided evidence of the locations of foraging areas associated with nesting in the northern Red Sea (Attum et al., 2014). Recently, three green turtles were followed using satellite transmitters to foraging areas in the southern portion of the Red Sea from nesting areas located in Oman (Rees et al., 2012, 2018; Pilcher et al., 2021b). Although, the migrations to foraging areas by sea turtles that nest at sites in the northern Red Sea have received little attention (Attum et al., 2014; Mancini et al., 2015, 2018), their use of nesting sites and internesting habitat has recently been described in detail (Shimada et al., 2021a,b).

Surveys of the biology of green turtles nesting at Ras Baridi began in 1987 (Miller, 1989). In 1989 the National Center for Wildlife (NCW) [formerly the National Commission for Wildlife Conservation and Development] initiated detailed studies of multiple aspects of the nesting turtles, including their 
morphology and their nesting success (Al-Merghani et al., 2000; Pilcher and Al-Merghani, 2000; Al-Mansi et al., 2003; Al-Mansi, 2016). In addition to studies concerning the turtles, physical characteristics of the beach and environmental factors were studied to determine their impact on the hatching success of eggs (Al-Mansi et al., 1991; Pilcher, 1999; Tanabe et al., 2020). Jensen et al. (2019) defined a unique genetic allele from the green turtles nesting at Ras Baridi. Recently, an assessment of the nesting population and the use of internesting habitat in the vicinity of the Ras Baridi nesting beaches was described (Shimada et al., 2021a).

In late 2009 the NCW began a research program with the goal of identifying the migratory routes and the foraging areas used by green turtles nesting at Ras Baridi. Herein we present the results of satellite tracking of 16 post-nesting green turtles from Ras Baridi on the Red Sea Coast of the Kingdom of Saudi Arabia between 2009 to 2014 .

\section{MATERIALS AND METHODS}

\section{Study Area}

Ras Baridi (N 24 $16^{\prime} 24.33^{\prime \prime}$; E $37^{\circ} 37^{\prime} 35.30^{\prime \prime}$ ) is located $60 \mathrm{~km}$ north of Yanbu on the eastern coast of Saudi Arabia, facing the north-central Red Sea (Figure 1) (for regional context see: Head, 1987; Tesfamichael and Pauly, 2016; Carvalho et al., 2019; Supplementary Material). Green turtles are the main species nesting at Ras Baridi, where the nesting season extends from August through November/December (Pilcher and Al-Merghani, 2000; Shimada et al., 2021b). An estimated 178 to 330 green turtles nest on the five well-developed pocket beaches (Shimada et al., 2021b; Figure 1). The beaches range from 50 to $1500 \mathrm{~m}$ long and are about $50 \mathrm{~m}$ wide. The other species that nests at Ras Baridi, at least infrequently, is the hawksbill (Eretmochelys imbricata) (Shimada et al., 2021b), which nests in low numbers throughout the region (Miller, 2020).

\section{Transmitter Attachment and Data Processing}

During the study period (December 2009 through October 2014), 16 female green turtles were selected to carry satellite transmitters. After oviposition had been completed, each turtle was corralled in a wooden-sided frame that prevented it from returning to the sea. A titanium tag (Stockbrands Co., Pty Ltd.) was attached to the trailing edge of the left front flipper of each turtle (Balazs, 1999). The curved carapace length (CCL) of each nesting female was measured using a flexible tape measure over the curve of the carapace along the midline from the anterior point at the midline of the nuchal scute to the posterior tip of the supra caudal scutes (CCLn-t, Bolten, 1999). The curved carapace width (CCW) was measured over the curve of the carapace from margin to margin at the widest part, perpendicular to the midline of the carapace (Supplementary Table 1).

Transmitter attachment was accomplished by washing the anterior carapace with disinfectant and rinsing the area with water. The second vertebral scute of the carapace (transmitter location) was gently rubbed with sandpaper and washed with acetone (Coyne et al., 2009). The transmitter was attached to the carapace with epoxy (PC-11 epoxy glue, Protective Coating Company), according to the manufacturer's instructions and established procedures (Coyne et al., 2009). The turtle was released after the epoxy had dried (approximately $90 \mathrm{~min}$ ) to return to the sea.

Turtles were tracked with Kiwisat 101 PTTs (Sirtrack Ltd.), programmed for a duty cycle of $8 \mathrm{~h}$ on/ $16 \mathrm{~h}$ off, and synchronized to operate during daylight hours to prolong battery life. Saltwater switches restricted transmission to periods when the unit was at the surface.

Filtering of the data from Argos used standard doppler-based geolocation technology. Locations were assigned an estimate of accuracy by the Argos system: class $0=>1,500 \mathrm{~m}$, class $1=>1,000 \mathrm{~m}$, class $2=>500 \mathrm{~m}$, and class $3=>150 \mathrm{~m}$, plus class $A$ and $B$ using Kalman filtering. Only data points from ARGOS estimated accuracy location classes 3, 2, 1, and A were included in the analysis (Hays et al., 2001). In addition, data points greater than $100 \mathrm{~km}$ from the previous location or that indicated a turtle speed greater than $5 \mathrm{~km} / \mathrm{h}$ (Troëng et al., 2005; Broderick et al., 2007) were omitted from the data set before analysis. Also, data points that were greater than $2 \mathrm{~m}$ above sea level or that were over land were omitted from the analysis (Attum et al., 2014).

The Satellite Tracking and Analysis Tool "STAT" (Coyne and Godley, 2005) was used to organize and analyze the data. Geographic information system software (ESRI ArcGIS 10.14) was used to map turtle movements. Cumulative distance traveled was calculated as the sum of the distances between contiguous locations measured using the geometry calculation in ArcGIS assuming straight-line movements between fixes. The speed for each turtle was calculated based on the sum of time intervals and the sum of distances measured between contiguous locations in each of three habitats: open water, coastal water, and foraging area. Turtles were deemed to have left the nesting beach when the signal locations indicated directional movement way from the nesting area (Pilcher et al., 2014). The $200 \mathrm{~m}$ depth contour was used to determine whether turtles moved into open water or remained along the coast because it is beyond the depth of seagrass growth (Duarte, 1991) and green turtle foraging dives (Lutcavage and Lutz, 1997). Turtles were deemed to have arrived at foraging areas when the rate of travel was consistently below $1 \mathrm{~km} / \mathrm{h}$ and signal positions indicated short distance, multidirectional movements separated by sharp acute angles (i.e., $<30^{\circ}$ ) (Schofield et al., 2010; Foley et al., 2013). In all cases, the boundaries between habitats were determined visually from the plotted points.

\section{RESULTS}

\section{Signals Received and Filtered}

The mean number of location signals received from the satellite transmitters affixed to the post-nesting turtles during their migrations to foraging habitats was 194.8 (Range: 45-666, $n=16$ ) (Table 1). The mean number of locations removed before analysis was 12.4 (Range: $4-24, n=16$ ), the majority of which were removed because the location was "over land" during the coastal 


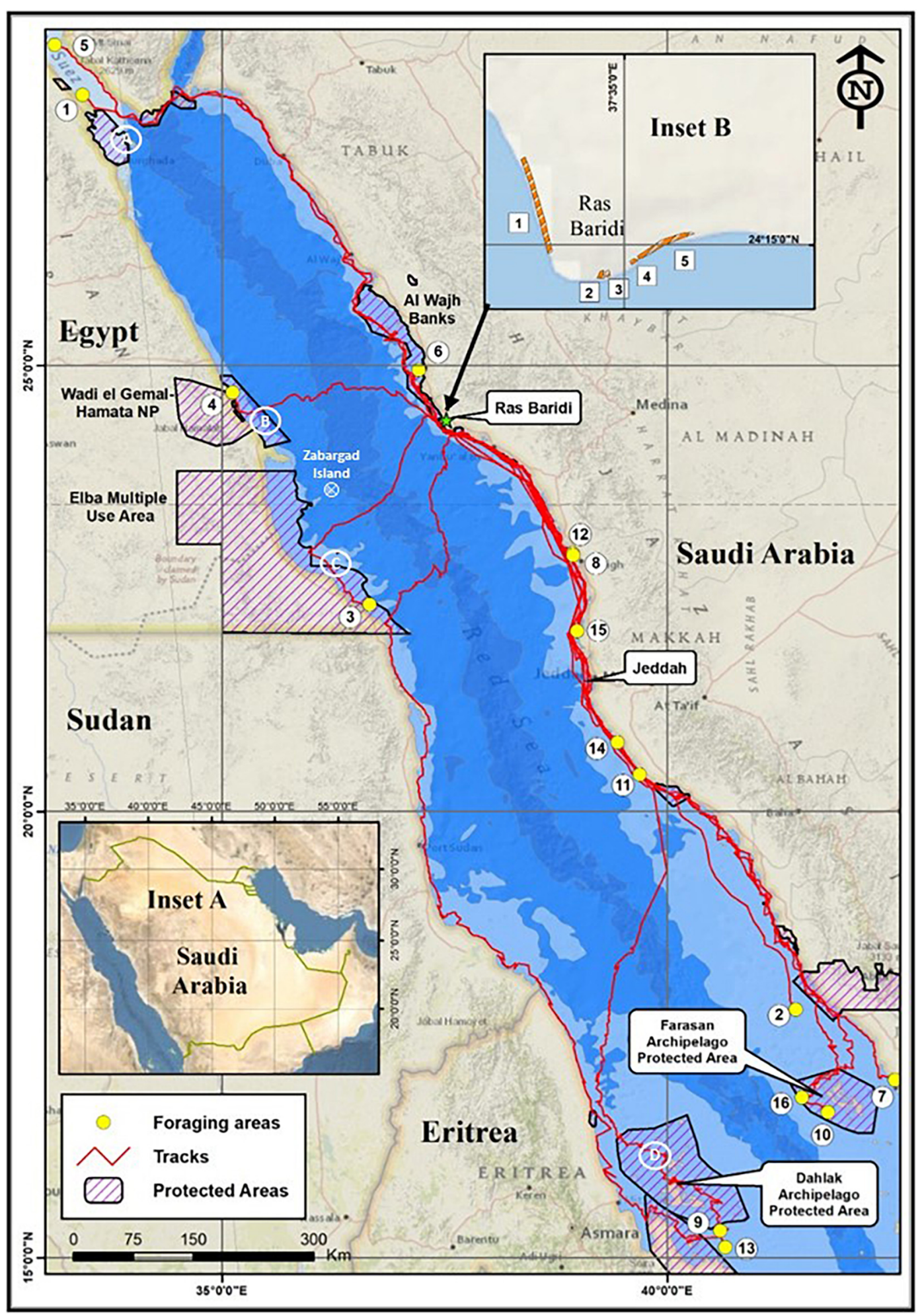

FIGURE 1 | Map of the Red Sea showing the distribution of foraging areas of 16 green turtles that nested at Ras Baridi on the eastern coast of Saudi Arabia. Inset A provides regional orientation. Inset B shows the distribution of beaches at Ras Baridi. Circled numbers = identification of forging areas used by 16 post-nesting green turtles in the present study. Green Star = Ras Baridi. White circled X = Zabargad Island; white circled letters = general location of foraging areas used by the green turtles tracked by Attum et al. (2014). Depth contours: light blue $=$ coastal shelf $<200 \mathrm{~m}$, medium blue $=>200 \mathrm{~m}$, dark blue $>1000 \mathrm{~m}$. Sources: National Geographic, Esri, DeLorme, HERE, UNEP-WCMC, USGS, NASA, ESA, METI, NRCAN, GEBCO, NOAA, IPC, and Esri, DigitalGlobe, GeoEye, i-cubed, USDA FSA, USGS, AEX, Getmapping, Aerogrid, IGN, IGP, swisstopo, and the GIS User Community by ESRI software 10.4. 
TABLE 1 | Summary of the numbers of locations used in the study, daily means in the open water and coastal habitats, and the reasons for removal of points.

\begin{tabular}{|c|c|c|c|c|c|c|c|c|}
\hline $\begin{array}{l}\text { Turtle } \\
\text { No. }\end{array}$ & $\begin{array}{l}\text { Total number } \\
\text { of Locations }\end{array}$ & $\begin{array}{l}\text { Number of } \\
\text { Locations Used }\end{array}$ & $\begin{array}{l}\text { Number in } \\
\text { Open water }\end{array}$ & $\begin{array}{l}\text { Daily Mean in } \\
\text { Open water }\end{array}$ & $\begin{array}{c}\text { Number in } \\
\text { Coastal water }\end{array}$ & $\begin{array}{l}\text { Daily Mean in } \\
\text { Coastal water }\end{array}$ & $\begin{array}{c}\text { Number of Locations } \\
\text { Removed }\end{array}$ & $\begin{array}{l}\text { Reasons for } \\
\text { Removal }\end{array}$ \\
\hline 1 & 155 & 141 & & & 141 & 8.29 & 14 & $5,2,1$ \\
\hline 2 & 163 & 144 & & & 144 & 9.6 & 19 & $5,4,1$ \\
\hline 3 & 172 & 167 & 49 & 26.59 & 118 & 15.23 & 5 & 5,1 \\
\hline 4 & 93 & 89 & 45 & 17.3 & 44 & 6.98 & 4 & 4,1 \\
\hline 5 & 147 & 137 & & & 137 & 7.86 & 10 & $5,3,4,1$ \\
\hline 6 & 95 & 71 & & & 71 & 24.66 & 24 & 5,1 \\
\hline 7 & 258 & 244 & & & 244 & 9.76 & 14 & $5,2,1$ \\
\hline 8 & 126 & 117 & & & 117 & 23 & 9 & 5,1 \\
\hline 9 & 109 & 100 & & & 100 & 16.67 & 9 & 5,1 \\
\hline 10 & 459 & 444 & 62 & 19.81 & 382 & 10.85 & 15 & $5,4,3$ \\
\hline 11 & 177 & 169 & & & 169 & 11.27 & 8 & 5,1 \\
\hline 12 & 100 & 94 & & & 94 & 18.8 & 6 & $5,2,1$ \\
\hline 13 & 666 & 649 & 74 & 19.7 & 575 & 12.83 & 17 & $5,3,1$ \\
\hline 14 & 140 & 118 & & & 118 & 12.16 & 22 & 5,1 \\
\hline 15 & 45 & 33 & & & 33 & 6.6 & 12 & $5,3,1$ \\
\hline 16 & 213 & 202 & & & 202 & 8.46 & 11 & $5,4,2,1$ \\
\hline Mean & 194.87 & 182.44 & 57.5 & 20.85 & 168.06 & 12.69 & 12.44 & \\
\hline (Min) & 45 & 33 & 45 & 17.3 & 33 & 6.6 & 4 & \\
\hline (Max) & 666 & 649 & 74 & 26.59 & 575 & 24.66 & 24 & \\
\hline Count & 16 & 16 & 4 & 4 & 16 & 16 & 16 & \\
\hline
\end{tabular}

Turtle numbers are shown on Figure 1. Codes for Reasons for Removal: 1. Accuracy of location = B, 2. Data points greater than 100 km from the previous location, 3. Speed between points was greater than $5 \mathrm{~km} / \mathrm{h}$, 4. Greater than $2 \mathrm{~m}$ above sea level, and 5. Over land.

movement phase of the migration of each turtle. The mean number of usable locations was 182.4 (Range: 33-649, $n=16$ ).

\section{Migration Paths}

The destinations of the 16 post-nesting female green turtles tracked by satellite transmitters from Ras Baridi to foraging areas demonstrated that they did not leave the Red Sea basin (Figure 1). The majority $(n=12)$ of the turtles used coastal migration routes within the $200 \mathrm{~m}$ bathymetry contour but a few $(n=4)$ crossed the deep trough (>1000 m deep, Head, 1987) of the Red Sea. The dispersal pattern shows that in any 1 year the turtles migrated to foraging areas located in different areas of the Red Sea (Figure 1 and Supplementary Table 2$)$. The majority $(n=10)$ remained along the coastal margin of Saudi Arabia while six of the turtles ended their journeys in other countries: Egypt $(n=4)$ and in Eritrea $(n=2)$.

Twelve turtles migrated along the coastal margin. Of these 12, three turtles migrated northward along the coast of Saudi Arabia. One of these stopped in Saudi Arabia and two continued to the Gulf of Suez. Five of the 12 turtles traveled southward along the eastern coast of Saudi Arabia to neritic foraging areas in the vicinity of Jeddah (Figure 1). Three turtles stopped along the coast north of Jeddah and two turtles continued southward to coastal feeding areas to the south of Jeddah. Four of the 12 turtles migrated much further south to the vicinity of the Farasan Archipelago (Figure 1). One finished its journey in the northern part of the area. One settled in the coastal area in front of the city of Jizan. The other two turtles traveled to the shallow water of the Farasan Archipelago.
The other four turtles of the 16 crossed the deep-water trough ( $>1000 \mathrm{~m}$, Head, 1987) of the Red Sea during their journeys to foraging areas in Egypt $(n=2)$ and Eritrea $(n=2)$ (Figure 1). One of these turtles crossed to the western side of the Red Sea and then traveled slightly northward to Wadi El Gemal-Hamata National Reserve (Egypt). The second turtle crossed the Red Sea in a southwesterly direction and then followed the coast southward to the vicinity of Halayib Island in the Elba Multiple Use Area. The third turtle crossed the Red Sea and continued southward along Sudanese coast to the Dahlak Archipelago in Eritrea. The fourth turtle moved southward along the eastern coast of Saudi Arabia for about half of its journey, then crossed the Red Sea, and continued southward on the western side to the Dahlak Archipelago.

\section{Post-nesting Migration Distance, Duration, and Rate of Travel}

The mean post-nesting migration distance traveled by the 16 turtles in the present study was $784.9 \mathrm{~km}$ ( \pm Standard Deviation of the Sample $=505.78 \mathrm{~km}$ ) (Table 2). The shortest distance traveled was to the vicinity of Umm Sihr Island located $130 \mathrm{~km}$ to the North of Ras Baridi. The longest journey covered a distance of $1749 \mathrm{~km}$, ending in the Dahlak Archipelago of Eritrea. The duration of migrations between the nesting site at Ras Baridi and the foraging areas ranged from 3 to 47.1 days ( mean $=17.1 \pm 12.6$ days, $n=16$, Table 2 ). The turtle that traveled the shortest distance did so in 3 days and the turtle that traveled the longest distance required 38 days to complete its journey. The turtle that traveled the longest time covered a distance of 
TABLE 2 | Summary of data for each of the 16 green turtles followed by satellite tags from nesting at Ras Baridi, Saudi Arabia, including duration of signal reception, total migration distance, travel days, speed and distance traveled in open water and along the coast, residence time in foraging area before loss of signal, and speed in foraging area.

\begin{tabular}{|c|c|c|c|c|c|c|c|c|c|c|c|}
\hline $\begin{array}{l}\text { Turtle } \\
\text { No. }\end{array}$ & $\begin{array}{c}\text { Signal } \\
\text { Reception } \\
\text { Duration } \\
\text { (Days) }\end{array}$ & $\begin{array}{c}\text { Total } \\
\text { Migration } \\
\text { Distance } \\
\text { (km) }\end{array}$ & $\begin{array}{l}\text { Total } \\
\text { Travel } \\
\text { Days }\end{array}$ & $\begin{array}{c}\text { Open Water } \\
\text { Migration } \\
\text { Distance }\end{array}$ & $\begin{array}{c}\text { Open } \\
\text { Water } \\
\text { Travel } \\
\text { Days }\end{array}$ & $\begin{array}{l}\text { Open } \\
\text { Water } \\
\text { Speed } \\
\text { (km/h) }\end{array}$ & $\begin{array}{c}\text { Coastal water } \\
\text { Migration } \\
\text { Distance }\end{array}$ & $\begin{array}{c}\text { Travel Days } \\
\text { in Coastal } \\
\text { Water }\end{array}$ & $\begin{array}{c}\text { Coastal } \\
\text { Speed } \\
(\mathrm{km} / \mathrm{h})\end{array}$ & $\begin{array}{c}\text { Foraging } \\
\text { Area } \\
\text { Residence } \\
\text { Days }\end{array}$ & $\begin{array}{c}\text { Foraging } \\
\text { Area } \\
\text { Speed } \\
\text { (km/h) }\end{array}$ \\
\hline 1 & 283 & 795 & 17 & & & & 795 & 17 & 1.95 & 251 & 0.051 \\
\hline 2 & 157 & 913 & 15 & & & & 913 & 15 & 2.54 & 56 & 0.43 \\
\hline 3 & 709 & 380 & 8.9 & 210 & 2.6 & 3.31 & 170 & 6.3 & 1.12 & 672 & 0.38 \\
\hline 4 & 1118 & 344 & 7 & 251 & 3.4 & 3.07 & 93 & 2.7 & 1.44 & 1111 & 0.42 \\
\hline 5 & 285 & 935 & 22 & & & & 935 & 22 & 1.77 & 248 & 0.55 \\
\hline 6 & 280 & 130 & 3 & & & & 130 & 3 & 1.81 & 635 & 0.69 \\
\hline 7 & 127 & 1230 & 25 & & & & 1230 & 25 & 2.05 & 92 & 0.49 \\
\hline 8 & 188 & 290 & 6 & & & & 290 & 6 & 2.01 & 171 & 0.39 \\
\hline 9 & 142 & 1749 & 38 & 245 & 3.1 & 3.31 & 1504 & 34.9 & 1.79 & 110 & 0.57 \\
\hline 10 & 129 & 1304 & 26 & & & & 1304 & 26 & 2.09 & 100 & 0.44 \\
\hline 11 & 173 & 634 & 15 & & & & 634 & 15 & 1.76 & 155 & 0.59 \\
\hline 12 & 322 & 271 & 5 & & & & 271 & 5 & 2.26 & 275 & 0.41 \\
\hline 13 & 166 & 1542 & 47.1 & 305 & 3.9 & 3.28 & 1237 & 43.2 & 1.19 & 112 & 0.77 \\
\hline 14 & 218 & 480 & 10 & & & & 480 & 10 & 2 & 178 & 0.4 \\
\hline 15 & 108 & 325 & 5 & & & & 325 & 5 & 2.71 & 101 & 0.61 \\
\hline 16 & 229 & 1237 & 24 & & & & 1237 & 24 & 2.15 & 195 & 0.58 \\
\hline Mean & 289.6 & 784.9 & 17.1 & 252.8 & 3.3 & 3.2 & 721.8 & 16.3 & 1.9 & 278.9 & 0.5 \\
\hline StDev.s ${ }^{\star}$ & 262.80 & 505.78 & 12.63 & 39.25 & 0.54 & 0.12 & 482.40 & 12.11 & 0.43 & 285.70 & 0.16 \\
\hline Min & 108 & 130 & 3 & 210 & 2.6 & 3.07 & 93 & 2.7 & 1.12 & 56 & 0.051 \\
\hline Max & 1118 & 1749 & 47.1 & 305 & 3.9 & 3.31 & 1504 & 43.2 & 2.71 & 1111 & 0.77 \\
\hline Count & 16 & 16 & 16 & 4 & 4 & 4 & 16 & 16 & 16 & 16 & 16 \\
\hline
\end{tabular}

*Stdev.s = Standard Deviation of the Sample.

Turtle numbers are shown on Figure 1.

$1542 \mathrm{~km}$. The mean rate of travel of turtles while moving along the coast was $1.9 \pm 0.426 \mathrm{~km} / \mathrm{h}(n=16$, Table 2$)$. The mean speed of four turtles while crossing the deep water of the Red Sea was $3.24 \pm 0.116 \mathrm{~km} / \mathrm{h}(n=4$, Table 2$)$. The mean speed dropped to $0.49 \pm 0.163 \mathrm{~km} / \mathrm{h}(n=16$, Table 2$)$ in the foraging areas. The rate of travel suggests that the turtles did not stop for any length of time during their migrations.

The mean reception period for a satellite signal was $289.6 \pm 262.8$ days. The longest reception period was 1118 days after the initial tagging, and the shortest reception period was 108 days (Table 2). Transmitters remained active for an average of $278.9 \pm 285.7$ days $(n=16)$ after the behavior of the turtles indicated they were foraging rather than traveling (Table 2).

\section{Managed and/or Protected Areas}

The destinations of the migrations were inside $(n=5)$ and outside $(n=11)$ managed and/or protected areas. Two turtles (\#10, \#16) concluded their migrations in the Farasan Islands Resource Use Reserve, and one turtle (\#6) was tracked to the Al Wajh Bank Resource Use Reserve in Saudi Arabia (Figure 1). The remaining two turtles (\#4, \# 3) crossed the Red Sea to reach foraging areas in Wadi el Gemal-Hamata National Park, which is a multiple use management area, and to the Elba Multiple Use Management Area situated along the central and southern coast of Egypt, respectively. The other 11 turtles were tracked to foraging locations outside protected areas. Six turtles settled within $30 \mathrm{~km}$ of a protected area and five stopped in foraging areas without nearby protected areas (i.e., $>30 \mathrm{~km}$ ) along the narrow coastal margin to the North and South of Jeddah (Figure 1).

\section{DISCUSSION}

Satellite tracking of marine turtle movements between their foraging and nesting areas has begun to fill in much of the missing information on migratory movements and habitat use in the region of the Arabian Peninsula (Rees et al., 2012, 2018; Pilcher et al., 2020, 2021a,b). However, very little information is known about green turtle migrations or the locations of their foraging areas in the Red Sea basin (Attum et al., 2014; Mancini et al., 2015, 2018; Shimada et al., 2021a,b).

The destinations of these 16 post-nesting green turtles showed they remained within the Red Sea basin (Figure 1). Their destinations indicate that turtles nesting at Ras Baridi originated from at least 11 foraging areas located in three countries (Saudi Arabia, Egypt, Eritrea), with most foraging in neritic habitat in Saudi Arabia (Figure 1 and Supplementary Table 2). The majority followed routes along the coastal margin within the 200 m bathymetry contour but a few crossed the deep trough (>1000 m deep) of the Red Sea. The migration routes illustrate that turtles which migrated to the same destination 
did not necessarily follow the same migratory route and that turtles which did follow the same general migratory route did not necessarily stop at the same foraging area. While in route along the coast and over deep-water areas, they swam at speeds comparable to those reported by others, with migration speeds over deep-water being faster (e.g., Papi et al., 1995; Cheng, 2000 and citations therein; Godley et al., 2002; Ferreira et al., 2020).

The green turtles tracked from Ras Baridi showed the Type A1 migratory behavior (Godley et al., 2008) described for green turtles in the Mediterranean (Godley et al., 2002). Although the green turtles from Ras Baridi behaved in a similar manner to those in the western Mediterranean (Godley et al., 2002; Stokes et al., 2015), there were differences. Only four of the turtles from Ras Baridi crossed deep water of the Red Sea, whereas all of the turtles tracked from Cyprus crossed deep water during part of their migrations. All the turtles from Ras Baridi and Cyprus utilized neritic habitat during part of their migrations to reach foraging areas. However, the migratory routes of the turtles from Ras Baridi were shorter (mean, range: 784.9, 130-1749 km vs. $1363.7,322.6-2199.6 \mathrm{~km}$, Godley et al., 2002; 1283, 181 to $2641 \mathrm{~km}$, Stokes et al., 2015) and, as a consequence, required shorter travel times (mean, range: 17.1 , 3-47 days vs. 27.6, 8.243.8 days, Godley et al., 2002, 2008, and 36, 6-80 days, Stokes et al., 2015) to reach their destinations.

The migration distances of green turtles vary widely throughout their global range, mostly as the result of the relative locations of nesting and foraging habitats in the context of the physiography of the regional environment (Godley et al., 2002; Blanco et al., 2012; Read et al., 2014; Stokes et al., 2015; Mettler et al., 2019). Within the long narrow Red Sea (Head, 1987; Carvalho et al., 2019), green turtles behave in a similar manner and likely for the same reasons because some migrated relatively short distances and others moved more than $1000 \mathrm{~km}$ (i.e., Zabargad Island: 140-940 km, Attum et al., 2014; Ras Baridi: $130-1749 \mathrm{~km}$, present study).

The four post-nesting green turtles tracked from Zabargad Island provided the initial view of habitat areas used by green turtles that nested in the northern Red Sea region (Attum et al., 2014; Figure 1). The locations of their destinations and those of the current study indicate that turtles using these separate nesting locations share some general foraging areas. The proximity of the destinations identifies four general areas that are important to the foraging aggregations of green turtles in the western Red Sea [i.e., Gamsha Archipelago (Egypt), the Wadi el Gemal-Hamata NP and Elba Multiple use Area (Egypt), and the Dahlak Archipelago (Eritrea)] (Figure 1). In addition, the turtles from Ras Baridi identified new foraging habitats on the eastern side of the Red Sea (i.e., coastal margin in the vicinity of Jeddah and in the Farasan Archipelago) that are connected to the turtles nesting at Ras Baridi.

The distribution of the foraging areas used by these northern nesting turtles corroborates the genetic difference (allele cmP71.1, Jensen et al., 2019) reported from 16 tissue samples collected in 1993 because all tracked turtles remained within the Red Sea. The genetic difference and the ancestral link to the green turtles nesting in Oman (Jensen et al., 2019) are further supported because both metal flipper tags and satellite tags applied in Oman have been carried to the southern Archipelagos of the Red Sea (Ross and Barwani, 1982; Salm et al., 1993; Rees et al., 2012, 2018; Pilcher et al., 2021b) indicating that these foraging areas support mixed foraging stock. Although the combination of these independent methods (i.e., genetics, satellite tracking) differentiates the nesting population at Ras Baridi as being unique, additional sampling of the genetic composition of turtles from other nesting locations in the Red Sea basin is needed to define the linkages among the nesting aggregations and foraging habitats of green turtles. This information has direct implications on the development of multinational conservation management of marine turtles and their habitats in the northern Red Sea.

The transboundary routes of migrating marine turtles expose them to various anthropogenic threats, including becoming bycatch in fishing operations (PERSGA, 2007; Stokes et al., 2015; Gajdzik et al., 2021). In the Red Sea basin marine turtles are not typically the target of fishing activities and they are protected both inside and outside of National Parks and other protected areas throughout the region by a mixture of national laws and international agreements (PERSGA, 2003; Mancini et al., 2015; Shepherd, 2015; Phillott and Rees, 2020). However, because most migrate by means of the coastal shelf where much of the fishing activity occurs, they are subject to incidental capture. In addition, they reside and forage in areas where seagrasses and alga grow, which are also areas of intense fishing activity, thus making them vulnerable to being caught in artisanal and commercial fishing operations. Studies conducted elsewhere have demonstrated that the likelihood of bycatch increases when fishing grounds overlap with turtle high-use areas (Stokes et al., 2015; Monteiro et al., 2016) which can have severe impacts on turtle populations (Lucchetti et al., 2019). Within the Red Sea marine turtles are caught in both artisanal and commercial fisheries throughout the region (Hariri et al., 2002; Teclemariam et al., 2009; Mebrahtu, 2013, 2015; Mancini et al., 2015; Rouphael et al., 2015; Pilcher et al., 2021b) but there is very little published information concerning this impact on the turtle populations. Additional information on the habitats (i.e., foraging habitat, migratory routes, and internesting habitat) used by the turtles and details of fishing operations is required to develop plans that protect habitat and reduce bycatch (Casale, 2008; Wallace et al., 2013; Casale et al., 2018).

Studies conducted elsewhere have shown positive benefit for sea turtles in marine protected areas (Scott et al., 2012; Hart et al., 2013; Revuelta et al., 2015; Doherty et al., 2020). For green turtles, this results from the protection of seagrass and algal habitats over large areas along with the management of fishing and other anthropogenic activities to benefit the marine fauna, including marine turtles (PERSGA, 2007; Read et al., 2014). Because marine turtles demonstrate high fidelity to foraging areas (Schofield et al., 2010, 2013; Pilcher et al., 2020; Shimada et al., 2020), following turtles via satellite telemetry can be used to identify important foraging habitat and contribute to identifying locations for the creation of new 
protected areas (Maxwell et al., 2011; Pilcher et al., 2014, 2021a; Esteban et al., 2018; Roberts et al., 2021). In the present study about two-thirds of the destinations of the turtles from Ras Baridi were within or close to $(<30 \mathrm{~km})$ protected or managed areas (Figure 1). The selection of these areas by the turtles is associated with the distribution and growth of seagrass (Duarte, 1991; Bjorndal, 1997; Serrano et al., 2018; Qurban et al., 2019; Stokes et al., 2019; Esteban et al., 2020). However, the current designated protected areas alone will not provide protection for all members of the foraging aggregations because marine turtles display complex movements within and among large and/or disjunct foraging areas throughout the year (Hawkes et al., 2006; Shimada et al., 2016; Dujon et al., 2018). The designation of additional smaller protected areas that contain a range of habitats would benefit foraging turtles of different age/size classes as well as other marine species (Hays et al., 2021), particularly along the narrow coastal foraging areas located to the North and South of Jeddah. Because the destinations of the 16 post-nesting green turtles indicate that these turtles are using more areas than are currently within the designated management areas of the Red Sea, a review of existing and proposed management areas with a view to assess their effectiveness in protecting at-risk species and to provide habitat for multiple marine species is warranted (Rouphael et al., 2015; Gajdzik et al., 2021).

\section{CONCLUSION}

The satellite tracking of 16 post-nesting female green turtles (Chelonia mydas) to foraging areas located within the Red Sea basin enhances the knowledge-base of the regional ecology of green turtles because it provides both confirming and new information about marine turtles in the region. As would be expected, the majority of the turtles migrated along the shallow coastal corridor to reach wide-spread foraging areas; however, four traversed the deep trough of the Red Sea during their journeys. The dispersal of these turtles establishes connectivity for turtles nesting at Ras Baridi with multiple foraging habitats throughout the Red Sea, which is essential information for research and conservation management. Previously, a connection was shown for turtles in the southern part of the Red Sea to the nesting sites in Oman. However, the turtles nesting in the northern part of the Red Sea at Ras Baridi have now been shown to remain within the Red Sea basin. These turtles have a unique allele which confirms their separation from nesting turtles in Oman. In combination, this information will aid future mixed stock analysis and will contribute to better regional conservation management.

Some of the turtles used different migratory pathways to reach the same destination area and passed through the territorial waters of different countries that border the Red Sea. It follows that during their migration the turtles were exposed to different unquantified threatening processes depending on their route and the fishing operations occurring along the way. The identification of connecting corridors along the coast may be used to assist in the revision and standardization of fishery management guidelines to reduce bycatch of green sea turtles, especially in trawl and gillnet fisheries, and to support the development of additional marine protected areas. The identification of connectivity between nesting sites and transboundary foraging areas reinforces the need for multi-national cooperation to ensure that research and conservation management efforts are effective in the Red Sea. Our study demonstrates that regional and local studies contribute important information concerning marine turtle migrations and provides context for cooperative conservation decision-making within the region.

\section{DATA AVAILABILITY STATEMENT}

The original contributions presented in the study are included in the article/Supplementary Material, further inquiries can be directed to the corresponding author/s.

\section{ETHICS STATEMENT}

The animal study was reviewed and approved by Saudi Wildlife Authority Projects Committee.

\section{AUTHOR CONTRIBUTIONS}

AA-M designed the study. AA-M, AS, BA, AHA, AAA, and RA conducted the field work. AA-M and JM wrote the manuscript. All authors contributed to the editing of the manuscript.

\section{FUNDING}

Support and funding for this study was provided by the National Center for Wildlife and King Abdulaziz City for Science and Technology.

\section{ACKNOWLEDGMENTS}

We wish to thank His Highness Prince Bandar bin Saud, former president of the Saudi Wildlife Authority, for his support and encouragement to implement this project. Also, we thank Dr. Osama Fageeha Deputy Minister for Environment, and Dr. Muhammad Qurban, CEO of the National Center for Wildlife, for their guidance in publishing this information and Mr. Hany Ibrahim Mohamed Elnagar for assistance with the mapping. The editor and reviewers provided constructive criticism on the manuscript.

\section{SUPPLEMENTARY MATERIAL}

The Supplementary Material for this article can be found online at: https://www.frontiersin.org/articles/10.3389/fmars.2021. 758592/full\#supplementary-material 


\section{REFERENCES}

Al-Mansi, A. M. (2016). Sea Turtles in the Red Sea and the Arabian Gulf, Saudi Arabia. Report. Riyadh: Saudi Wildlife Authority, 1-43.

Al-Mansi, A. M., Nawab, A. A., and Sagga, A. M. S. (1991). Sediment characteristics of green turtle nesting beaches on the eastern Red Sea coast. Bull. Fac. Sci. Alex. Univ. 31, 384-401.

Al-Mansi, A. M., Sambas, A. Z., and Badawe, S. F. (2003). The Marine Turtles in Saudi Arabia: their Biology and Conservation. PERSGA Technical Report. Jeddah: PERSGA, 1-43.

Al-Merghani, M., Miller, J. D., Pilcher, N. J., and Al-Mansi, A. (2000). The green and hawksbill turtles in the Kingdom of Saudi Arabia: synopsis of nesting studies. Fauna Saudi Arabia 18, 369-384.

Attum, O., Kramer, A., Mahmoud, T., and Fouda, M. (2014). Post-nesting migrations patterns of green turtles (Chelonia mydas) from the Egyptian Red Sea. Zool. Middle East 60, 299-305. doi: 10.1080/09397140.2014.962833

Balazs, G. H. (1999). "Factors to consider in the tagging of sea turtles," in Research and Management Techniques for the Conservation of Sea Turtles. IUCN/SSC Marine Turtle Specialist Group Publication No. 4, eds K. L. Eckert, K. Bjorndal, A. Abreu-Grobois, and M. Donnelly (Washington, DC: IUCN/SSC Marine Turtle Specialist Group), 101-109.

Bjorndal, K. A. (1997). "Foraging ecology and nutrition of sea turtles," in The Biology of Sea Turtles, eds P. L. Lutz and J. A. Musick (Boca Raton, FL: CRC Press), 199-232.

Bjorndal, K. A., Bolten, A. B., and Troëng, S. (2005). Population structure and genetic diversity in green turtles nesting at Tortuguero, Costa Rica, based on mitochondrial DNA control region sequences. Mar. Biol. 147, 1449-1457. doi: 10.1007/s00227-005-0045-y

Blanco, G. S., Morreale, S. J., Bailey, H., Seminoff, J. A., Paladino, F. V., and Spotila, J. R. (2012). Post-nesting movements and feeding grounds of a resident East Pacific green turtle Chelonia mydas population from Costa Rica. Endanger. Species Res. 18, 233-245. doi: 10.3354/esr00451

Blumenthal, J. M., Solomon, J. L., Bell, C. D., Austin, T. J., Ebanks-Petrie, S. G., Coyne, M. S., et al. (2006). Satellite tracking highlights the need for international cooperation in marine turtle management. Endanger. Species Res, 7, 1-11.

Bolker, B. M., Okuyama, T., Bjorndal, K. A., and Bolten, A. B. (2007). Incorporating multiple mixed stocks in mixed stock analysis, 'many-to-many' analyses. Mol. Ecol. 16, 685-695. doi: 10.1111/j.1365-294X.2006.03161.x

Bolten, A. B. (1999). “Techniques for measuring sea turtles," in Research and Management Techniques for the Conservation of Sea Turtles. (IUCN/SSC Marine Turtle Specialist Group) Publication No. 4, eds K. L. Eckert, K. A. Bjorndal, F. A. Abreu-Grobois, and M. Donnelly (Washington, DC: IUCN/SSC Marine Turtle Specialist Group), 110-114.

Bourjea, J., Mortimer, J. A., Garnier, J., Okemwa, G., Godley, B. J., Hughes, G., et al. (2015). Population structure enhances perspectives on regional management of the western Indian Ocean green turtle. Conserv. Genet. 16, 1069-1083. doi: 10.1007/s10592-015-0723-3

Bradshaw, P. J., Broderick, A. C., Carreras, C., Inger, R., Fuller, W., Snape, R., et al. (2017). Satellite tracking and stable isotope analysis highlight differential recruitment among foraging areas in green turtles. Mar. Ecol. Prog. Ser. 582, 201-214. doi: 10.3354/meps 12297

Broderick, A. C., Coyne, M. S., Fuller, W. J., Glen, F., and Godley, B. J. (2007). Fidelity and over-wintering of sea turtles. Proc. R. Soc. B Biol. Sci. 274, $1533-$ 1539. doi: 10.1098/rspb.2007.0211

Carreras, C., Pascual, M., Cardona, L., Marco, A., Bellido, J. J., Castillo, J. J., et al. (2011). Living together but remaining apart, Atlantic and Mediterranean loggerhead sea turtles (Caretta caretta) in a shared feeding ground. J. Hered. 102, 666-677. doi: 10.1093/jhered/esr089

Carvalho, S., Kürten, B., Krokos, G., Hoteit, I., and Ellis, J. (2019). “The Red Sea," in World Seas, An Environmental Evaluation. The Indian Ocean to the Pacific, Vol. II, ed. C. Sheppard (Amsterdam: Elsevier), 49-74.

Casale, P. (2008). Incidental Catch of Marine Turtles in the Mediterranean Sea: Captures, Mortality, Priorities. Rome: WWF. doi: 10.1111/j.1467-2979.2010. 00394.x

Casale, P., Broderick, A. C., Camiñas, J. A., Cardona, L., Carreras, C., Demetropoulos, A., et al. (2018). Mediterranean Sea Turtles: current knowledge and priorities for conservation and research. Endanger. Species Res. 36, 229-267. doi: 10.3354/esr00901
Cheng, I. J. (2000). Post-nesting migrations of green turtles (Chelonia mydas) at Wan-An Island, Penghu Archipelago, Taiwan. Mar. Biol. 137, 747-754. doi: $10.1007 / \mathrm{s} 002270000375$

CITES (2021). Convention on International Trade of Endangered Species: Green Turtle. Available online at: https//www.cites.org (accessed February 12, 2021).

Coyne, M. S., and Godley, B. J. (2005). Satellite Tracking and Analysis Tool (STAT), an integrated system for archiving, analyzing and mapping animal tracking data. Mar. Ecol. Prog. Ser. 301, 1-7. doi: 10.3354/meps301001

Coyne, M., Godfrey, M., Godley, B., and Lay, K. (2009). Hard Shell Sea Turtle PTT Attachment Protocol. 1-8. Available online at: www.Seaturtle.org (accessed March 20, 2018).

Dethmers, K. E., Jensen, M. P., FitzSimmons, N. N., Broderick, D., Limpus, C. J., and Moritz, C. (2010). Migration of green turtles (Chelonia mydas) from Australasian feeding grounds inferred from genetic analyses. Mar. Freshwater Res. 61, 1376-1387. doi: 10.1071/mf10084

Doherty, P. D., Broderick, A. C., Godley, B. J., Hart, K. A., Phillips, Q., Sanghera, A., et al. (2020). Spatial ecology of sub-adult green turtles in coastal waters of the Turks and Caicos Islands, implications for conservation management. Front. Mar. Sci. 7:690. doi: 10.3389/fmars.2020.00690

Duarte, C. M. (1991). Seagrass depth limits. Aquat. Bot. 40, 363-377. doi: 10.1016/ 0304-3770(91)90081-f

Dujon, A. M., Schofield, G., Lester, R. E., Papafitsoros, K., and Hays, G. C. (2018). Complex movement patterns by foraging loggerhead sea turtles outside the breeding season identified using Argos-linked Fastloc-Global Positioning System. Mar. Ecol. Evol. Perspect. 39:e12489. doi: 10.1111/maec.12489

Dunn, D. C., Harrison, A. L., Curtice, C., DeLand, S., Donnelly, B., Fujioka, E., et al. (2019). The importance of migratory connectivity for global ocean policy. Proc. R. Soc. B 286:20191472.

Dutton, P. H., LeRoux, R. A., LaCasella, E. L., Seminoff, J. A., Eguchi, T., and Dutton, D. L. (2018). Genetic analysis and satellite tracking reveal origin of the green turtles in San Diego Bay. Mar. Biol. 166:3. doi: 10.1007/s00227-0183446-4

Egevang, C., Stenhouse, I. J., Phillips, R. A., Petersen, A., Fox, J. W., and Silk, J. R. D. (2010). Tracking of Arctic Terns Sterna Paradisaea Reveals Longest Animal Migration. Proc. Natl. Acad. Sci. U.S.A. 107, 2078-2081. doi: 10.1073/ pnas.0909493107

Esteban, N., Mortimer, J. A., Stokes, H. J., Laloë, J.-O., Unsworth, R. K. F., and Hays, G. C. (2020). A global review of green turtle diet: sea surface temperature as a potential driver of omnivory levels. Mar. Biol. 167:183. doi: 10.1007/s00227020-03786-8

Esteban, N., Unsworth, R. K. F., Gourlay, J. B. Q., and Hays, G. C. (2018) The discovery of deep-water seagrass meadows in a pristine Indian Ocean wilderness revealed by tracking green turtles. Mar. Pollut. Bull. 134, 99-105. doi: 10.1016/j.marpolbul.2018.03.018

Ferreira, L. C., Thums, M., Fossette, S., Wilson, P., Shimada, T., Tucker, A. D., et al. (2020). Multiple satellite tracking datasets inform green turtle conservation at a regional scale. Divers. Distrib. 27, 249-266. doi: 10.1111/ddi. 13197

Foley, A. M., Schroeder, B. A., Hardy, R., MacPherson, S. L., Nicholas, M., and Coyne, M. S. (2013). Postnesting migratory behavior of loggerhead sea turtles Caretta caretta from three Florida rookeries. Endanger. Species Res. 21, 129-142. doi: 10.3354/esr00512

Frazier, J. G., Bertrum, G. C., and Evans, P. S. H. (1987). "Turtles and Marine Mammals," in Key Environments - Red Sea, eds A. J. Edwards and S. M. Head (Amsterdam: Pergamon Press), 288-314. doi: 10.1016/b978-0-08-028873-4. 50019-0

Gajdzik, L., Green, A. L., Cochran, J. E. M., Hardenstine, R. S., Tanabe, L. K., and Berumen, M. L. (2021). Using species connectivity to achieve coordinated largescale marine conservation efforts in the Red Sea. Mar. Pollut. Bull. 166:112244. doi: 10.1016/j.marpolbul.2021.112244

Gladstone, W. (2002). Fisheries of the Farasan Islands (Red Sea). Naga WorldFish Center Q. 25, 30-34.

Godley, B. J., Barbosa, C., Bruford, M., Broderick, A. C., Catry, P., Coyne, M. S., et al. (2010). Unravelling migratory connectivity in marine turtles using multiple methods. J. Appl. Ecol. 47, 769-778. doi: 10.1111/j.1365-2664.2010. 01817.x

Godley, B. J., Richardson, S., Broderick, A. C., Coyne, M. S., Glen, F., and Hays, G. C. (2002). Long-term satellite telemetry of the movements and habitat 
utilisation by green turtles in the Mediterranean. Ecography 25, 352-362. doi: 10.1034/j.1600-0587.2002.250312.x

Godley, B., Blumenthal, J., Broderick, A., Coyne, M., Godfrey, M. H., Hawkes, L. A., et al. (2008). Satellite tracking of sea turtles: where have we been and where do we go next. Endanger. Species Res. 4, 3-22. doi: 10.3354/esr00060

Hariri, K. I., Nichols, P., Krupp, F., Mishrigi, S., Barrania, A., Ali, A. F., et al. (2002). Status of the Living Marine Resources in the Red Sea and Gulf of Aden Region and Their Management. Strategic Action Programme for the Red Sea and Gulf of Aden, Jeddah, Saudi Arabia. Regional Organization for the Conservation of the Environment of the Red Sea and Gulf of Aden. Jeddah: PERSGA, $1-149$.

Hart, K. M., Iverson, A. R., Benscoter, A. M. L., Fujisaki, I., Cherkiss, M. S., Pollock, C., et al. (2017). Resident areas and migrations of female green turtles nesting at Buck Island Reef National Monument, St Croix, US Virgin Islands. Endanger. Species Res. 32, 89-101. doi: 10.3354/esr00793

Hart, K. M., Iverson, A. R., Fujisaki, I., Lamont, M. M., Bucklin, D., and Shaver, D. J. (2018). Marine threats overlap key foraging habitat for two imperiled sea turtle species in the Gulf of Mexico. Front. Mar. Sci. 5:336. doi: 10.3389/fmars. 2018.00336

Hart, K. M., Lamont, M. M., Fujisaki, I., Tucker, A. D., and Carty, R. R. (2012). Common coastal foraging areas for loggerheads in the Gulf of Mexico, opportunities for marine conservation. Biol. Conserv. 145, 185-194. doi: 10. 1016/j.biocon.2011.10.030

Hart, K. M., Lamont, M. M., Iverson, A. R., and Smith, B. J. (2020). The importance of the northeastern Gulf of Mexico to foraging loggerhead sea turtles. Front. Mar. Sci. 7:330. doi: 10.3389/fmars.2020.0033

Hart, K. M., Zawada, D. G., Fujisaki, I., and Lidz, B. H. (2013). Habitat use of breeding green turtles Chelonia mydas tagged in Dry Tortugas National Park, Making use of local and regional MPAs. Biol. Conserv. 161, 142-154. doi: 10.1016/j.biocon.2013.03.019

Hawkes, L. A., Broderick, A. C., Coyne, M. S., Godfrey, M. H., Lopez-Jurado, L. F., Lopez-Suarez, P., et al. (2006). Phenotypically linked dichotomy in sea turtle foraging requires multiple conservation approaches. Curr. Biol. 16, 990-995. doi: 10.1016/j.cub.2006.03.063

Hays, G. C., Åkesson, S., Godley, B. J., Luschi, P., and Santidrian, P. (2001). The implications of location accuracy for the interpretation of satellite-tracking data. Anim. Behav. 61, 1035-1040. doi: 10.1006/anbe.2001.1685

Hays, G. C., and Hawkes, L. A. (2018). Satellite tracking sea turtles, opportunities and challenges to address key questions. Front. Mar. Sci. 5:432. doi: 10.3389/ fmars.2018.00432

Hays, G. C., Bailey, H., Bograd, S. J., Bowen, W. D., Campagna, C., Carmichael, R. H., et al. (2019). Translating marine animal tracking data into conservation policy and management. Trends Ecol. Evol. 34, 459-473. doi: 10.1016/j.tree. 2019.01.009

Hays, G. C., Broderick, A. C., Godley, B. J., Luschi, P., and Nichois, W. J. (2003). Satellite telemetry suggests high levels of fishing-induced mortality in marine turtles. Mar. Ecol. Prog. Ser. 262, 305-309. doi: 10.3354/meps26 2305

Hays, G. C., Mortimer, J. A., Ierodiaconou, D., and Esteban, N. (2014). Use of longdistance migration patterns of an endangered species to inform conservation planning for the world's largest marine protected area. Conserv. Biol. 28, 1636-1644. doi: $10.1111 /$ cobi.12325

Hays, G. C., Mortimer, J. A., Rattray, A., Shimada, T., and Esteban, N. (2021). High accuracy tracking reveals how small conservation areas can protect marine megafauna. Ecol. Appl. 31:e02418. doi: 10.1002/eap.2418

Head, S. M. (1987). "Introduction," in Key Environments, Red Sea, eds A. J. Edwards and S. M. Head (Amsterdam: Pergamon Press), 1-21.

Hernandez-Avila, I., Ocana, F. A., and Pech, D. (2020). Testing marine regionalscale hypotheses along the Yucatan continental shelf using soft-bottom macrofauna. PeerJ 8:e8227. doi: 10.7717/peerj.8227

Jensen, M. P., FitzSimmons, N. N., and Dutton, P. H. (2013). "Molecular genetics of sea turtles," in Biology of Sea Turtles, Vol. 3, eds J. Wyneken, K. J. Lohmann, and J. A. Musick (Boca Raton, FL: CRC Press), 135-154.

Jensen, M. P., Miller, J., Fitzsimmons, N. N., and Al-Merghani, M. (2019). Identification of Chelonia mydas populations in the kingdom of Saudi Arabia through regional genetic analyses. Mar. Turtle Newsl. 156, 16-20.

Lagabrielle, E., Lombard, A. T., Harris, J. M., and Livingstone, T.-C. (2018). Multiscale multi-level marine spatial planning: A novel methodological approach applied in South Africa. PLoS One 13:e0192582. doi: 10.1371/journal.pone. 0192582

Lascelles, B., Di Sciara, G. N., Agardy, T., Cuttelod, A., Eckert, S., Glowka, L., et al. (2014). Migratory marine species: their status, threats and conservation management needs. Aquat. Conserv. Mar. Freshw. Ecosyst. 24(Suppl. 2), 111127. doi: $10.1002 /$ aqc. 2512

Limpus, C. J., and Limpus, D. J. (2001). The loggerhead turtle, Caretta caretta, in Queensland: breeding migrations and fidelity to a warm temperate feeding area. Chelonian Conserv. Biol. 4, 142-153.

Limpus, C. J., Miller, J. D., Parmenter, C. J., Reimer, D., Mclachlan, N., and Webb, R. (1992). Migration of green (Chelonia mydas) and loggerhead (Caretta caretta) turtles to and from eastern Australian rookeries. Aust. Wildl. Res. 19, 347-358. doi: $10.1071 /$ wr 9920347

López-Hoffman, L., Chester, C. C., Semmens, D. J., Thogmartin, W. E., RodríguezMcGoffin, M. S., Merideth, R., et al. (2017). Ecosystem services from transborder migratory species: implications for conservation governance. Annu. Rev. Environ. Resour. 42, 509-539. doi: 10.1146/annurev-environ110615-090119

Lucchetti, A., Bargione, G., Petetta, A., Vasapollo, C., and Virgili, M. (2019). Reducing sea turtle bycatch in the Mediterranean mixed demersal fisheries. Front. Mar. Sci. 6:387. doi: 10.3389/fmars.2019.00387

Luschi, P. (2013). Long-Distance animal migrations in the oceanic environment: orientation and navigation correlates. ISRN Zool. 2013:631839. doi: 10.1155/ 2013/631839

Luschi, P., and Casale, P. (2014). Movement patterns of marine turtles in the Mediterranean Sea, a review. Ital. J. Zool. 81, 37-41. doi: 10.1080/11250003. 2014.963714

Luschi, P., Hays, G. C., and Papi, F. (2003). A review of long-distance movements by marine turtles, and the possible role of ocean currents. OIKOS 103, 293-302. doi: $10.1034 / j .1600-0706.2003 .12123 . x$

Luschi, P., Papi, F., Liew, H. C., Chan, E. H., and Bonadonna, F. (1996). Longdistance migration and homing after displacement in the green turtle (Chelonia mydas), a satellite tracking study. J. Comp. Physiol. A Sens. Neural Behav. Physiol. 178, 447-452.

Lutcavage, M. E., and Lutz, P. L. (1997). "Diving physiology," in Biology of Sea Turtles, eds P. L. Lutz and J. A. Musick (New York, NY: CRC Press), 277-296.

Mancini, A., Attum, O., Elsadek, I., and Rees, A. F. (2018). Satellite tracking studies show nesting site in Egypt is hub for adult green turtles of the Red Sea. Indian Ocean Turtle Newsl. 28, 10-12.

Mancini, A., Elsadek, I., and El-Alwany, M. A. N. (2015). "Marine turtles of the Red Sea," in The Red Sea, eds N. Rasul and I. Stewart (Berlin: Springer Earth System Sciences), 551-565. doi: 10.1007/978-3-662-45201-1_31

Mancini, A., Phillott, A. D., and Rees, A. F. (2019). Chelonia mydas (North Indian Ocean subpopulation) (errata version published in 2019). IUCN Red List Threatened Species 2019:e.T142121108A154845002.

Martin, T. G., Chadès, I., Arcese, P., Marra, P. P., Possingham, H. P., and Norris, D. R. (2007). Optimal conservation of migratory species. PLoS One 2:e751. doi: 10.1371/journal.pone.0000751

Maxwell, S. M., Breed, G. A., Nickel, B. A., Makanga-Bahouna, J., Pemo-Makaya, E., Parnell, R. J., et al. (2011). Using satellite tracking to optimize protection of long-lived marine species, olive ridley sea turtle conservation in Central Africa. PLoS One 6:e19905. doi: 10.1371/journal.pone.0019905

Mebrahtu, Y. (2015). Marine turtle conservation in the Eritrean Red Sea. Afr. Sea Turtle Newsl. 4, 28-30.

Mebrahtu, Y. T. (2013). Marine turtle update from the Eritrean Red Sea. Indian Ocean Turtle Newsl. 18, 2-5.

Mettler, E., Clyde-Brockway, C. E., Honarvar, S., and Paladino, F. V. (2019). Migratory corridor linking Atlantic green turtle, Chelonia mydas, nesting site on Bioko Island, Equatorial Guinea to Ghanaian foraging grounds. PLoS One 14:e0213231. doi: 10.1371/journal.pone.0213231

Meylan, A. B., Bowen, B. W., and Avise, J. C. (1990). A genetic test of natal homing versus social facilitation models for green turtle migration. Science 248, 724-727. doi: $10.1126 /$ science. 2333522

Miller, J. D. (1989). Marine Turtles, an Assessment of the Conservation Status of Marine Turtles in the Kingdom of Saudi Arabia. Report No. 9, Vol. 1. Jeddah: MEPA, 1-289.

Miller, J. D. (1997). "Reproduction in sea turtles," in The Biology of Sea Turtles, eds P. L. Lutz and J. A. Musick (Boca Raton, FL: CRC Press), 51-81. 
Miller, J. D. (2020). "Saudi Arabia (Kingdom of)," in Sea Turtles in the Middle East and South Asia Region, MTSG Annual Regional Report 2020. Report of the IUCN-SSC Marine Turtle Specialist Group, 2020, eds A. D. Phillott and A. F. Rees (Washington, DC: IUCN-SSC Marine Turtle Specialists Group), 208-244.

Monteiro, D. S., Estima, S. C., Gandra, T. B., Siva, A. P., Bugoni, L., Swimmer, Y., et al. (2016). Long-term spatial and temporal patterns of sea turtle strandings in southern Brazil. Mar. Biol. 163:247.

Palacios-Abrantes, J., Reygondeau, G., Wabnitz, C. C. C., and Cheung, W. W. L. (2020). The transboundary nature of the world's exploited marine species. Sci. Rep. 10:17668. doi: 10.1038/s41598-020-74644-2

Papi, F., Liew, H. C., Luschi, P., and Chan, E. H. (1995). Long-range migratory travel of a green turtle tracked by satellite, evidence for navigational ability in the open sea. Mar. Biol. 122, 171-175. doi: 10.1007/bf00348929

Pendoley, K. L., Schofield, G., Whittock, P. A., Ierodiaconou, D., and Hays, G. C. (2014). Protected species use of a coastal marine migratory corridor connecting marine protected areas. Mar. Biol. 161, 1455-1466. doi: 10.1007/s00227-0142433-7

PERSGA (2003). Status of the Living Marine Resources in the Red Sea and Gulf of Aden and Their Management, Strategic Action Programme for the Red Sea and Gulf of Aden. PERSGA Technical Series 4. Jeddah: PERSGA, 1-56.

PERSGA (2004). Regional Action Plan for the Conservation of Marine Turtles and Their Habitats in the Red Sea and Gulf of Aden. Jeddah: PERSGA, 1-65.

PERSGA (2006). State of the Marine Environment, Report for the Red Sea and Gulf of Aden. Jeddah: PERSGA, 1-260.

PERSGA (2007). Regional Action Plans for the Conservation of Marine Turtles, Seabirds and Mangroves in the Red Sea and Gulf of Aden. PERSGA Technical Series 12. Jeddah: PERSGA, 1-149.

PERSGA (2010). The Status of Coral Reefs in the Red Sea and Gulf of Aden, 2009. PERSGA Technical Series 16. Jeddah: PERSGA, 1-125.

Phillott, A. D., and Rees, A. F. (2020). "Regional overview," in Sea Turtles in the Middle East and South Asia Region: MTSG Annual Regional Report 2020, eds A. D. Phillott and A. F. Rees (Washington, DC: IUCN-SSC Marine Turtle Specialist Group), 1-25. doi: 10.1355/9789812309426-006

Pilcher, N. J. (1999). Cement dust pollution as a cause of sea turtle hatchling mortality at Ras Baridi, Saudi Arabia. Mar. Pollut. Bull. 38, 966-969.

Pilcher, N. J., and Al-Merghani, M. (2000). Reproductive biology of green turtles at Ras Baridi, Saudi Arabia. Herpetol. Rev. 31, 142-147.

Pilcher, N. J., Antonopoulou, M. A., Rodriguez-Zarate, C. J., Mateos-Molina, D., Das, H. S., Bugla, I., et al. (2021a). Movements of green turtles from foraging areas of the United Arab Emirates, regional habitat connectivity and use of marine protected areas. Mar. Biol. 168:10. doi: 10.1007/s00227-020-03815-6

Pilcher, N. J., Antonopoulou, M. A., Rodriguez-Zarate, C. J., Al-Sareeria, T. S., Baldwin, R., Willson, A., et al. (2021b). Wide-Scale population connectivity revealed by post-nesting migrations of green sea turtles from Ras $\mathrm{Al} \mathrm{Hadd,}$ Oman. Chelonian Conserv. Biol. 20, 10-17. doi: 10.2744/ccb-1462.1

Pilcher, N. J., Antonopoulou, M., Perry, L., Abdel-Moati, M. A., Al Abdessalaam, T. Z., Albeldawi, M., et al. (2014). Identification of Important Sea Turtle Areas (ITAs) for hawksbill turtles in the Arabian Region. J. Exp. Mar. Biol. Ecol. 460, 89-99. doi: 10.1016/j.jembe.2014.06.009

Pilcher, N. J., Rodriguez-Zarate, C. J., Antonopoulou, M. A., Mateos-Molina, D., Das, H. S., and Bugla, I. A. (2020). Combining laparoscopy and satellite tracking, Successful round-trip tracking of female green turtles from feeding areas to nesting grounds and back. Glob. Ecol. Conserv. 23:e01169. doi: 10.1016/ j.gecco.2020.e01169

Pilcher, N., Mahmud, S., Howe, S., Teclemariam, Y., and Weldeyohannes, S. (2006). An update on Eritrea's marine turtle programme and first record of olive ridley turtle nesting in the Red Sea. Mar. Turtle Newsl. 111, 16-18.

Plotkin, P. T. (2003). "Adult migrations and habitat use," in The Biology of Sea Turtles, Vol. 2, eds P. L. Lutz, J. A. Musick, and J. Wyneken (Boca Raton, FL: CRC Press), 225-241. doi: 10.1201/9781420040807.ch8

Qurban, M. A. B., Karuppasamy, M., Krishnakumar, P. K., Garcias-Bonet, N., and Duarte, C. M. (2019). "Seagrass distribution, composition and abundance along the Saudi Arabian Coast of Red Sea," in Oceanographic and Biological Aspects of the Red Sea, eds N. M. A. Rasul and I. C. F. Stewart (Cham: Springer Nature), 367-385.

Read, T. C., FitzSimmons, N. N., Wantiez, L., Jensen, M. P., Keller, F., Chateau, O., et al. (2015). Mixed stock analysis of a resident green turtle, Chelonia mydas, population in New Caledonia links rookeries in the South Pacific. Wildl. Res. 42, 488-499. doi: 10.1071/WR15064
Read, T. C., Wantiez, L., Werry, J. M., Farman, R., Petro, G., and Limpus, C. J. (2014). Migrations of green turtles (Chelonia mydas) between nesting and foraging grounds across the Coral Sea. PLoS One 9:e100083. doi: 10.1371/ journal.pone. 0100083

Rees, A. F., Al Kiyumi, A., and Papathanasopoulou, N. (2018). The Masirah turtle conservation project, the first turtle tracking on Masirah Island, Oman. Indian Ocean Turtle Newsl. 28, 23-26.

Rees, A. F., Al Kiyumi, A., Broderick, A. C., Papathanasopoulou, N., and Godley, B. J. (2012). Each to their own, Interspecific differences in migrations of Masirah Island turtles. Chelonian Conserv. Biol. 11, 243-248. doi: 10.2744/ccb1000.1

Rees, A., Alfaro-Shigueto, J., Barata, P., Bjorndal, K., Bolten, A., Bourjea, J., et al. (2016). Are we working towards global research priorities for management and conservation of sea turtles? Endanger. Species Res. 31, 337-382. doi: 10.3354/ esr00801

Revuelta, O., Hawkes, L., León, Y. M., Godley, B. J., Raga, J. A., and Tomás, J. (2015). Evaluating the importance of marine protected areas for the conservation of hawksbill turtles Eretmochelys imbricata nesting in the Dominican Republic. Endanger. Species Res. 27, 169-180. doi: 10.3354/esr0 0660

Roberts, K. E., Smith, B. J., Burkholder, D., and Hart, K. M. (2021). Evaluating the use of marine protected areas by endangered species: a habitat selection approach. Ecol. Solut. Evid. 2;e12035. doi: 10.1002/2688-8319.12035

Ross, J. P., and Barwani, M. A. (1982). "Review of sea turtles in the Arabian Area," in Biology and Conservation of Sea Turtles, ed. K. A. Bjorndal (Washington, DC: Smithsonian Institution Press), 373-382.

Rouphael, A., Marshall, N., Noor, N., El-Gawish, S., Baha-El-Din, S., Al-Bahry, W., et al. (2015). Do marine protected areas in the Red Sea afford protection to megafauna?: a reassessment nearly a decade on. J. Coast. Zone Manag. 18:1000411. doi: 10.4172/2473-3350.1000411

Russell, A. P., Bauer, A. M., and Johnson, M. K. (2005). "Migration in amphibians and reptiles: an overview of patterns and orientation mechanisms in relation to life history strategies," in Migration of Organisms: Climate Geography Ecology, ed. A. M. T. Elewa (Berlin: Springer-Verlag), 151-203.

Salm, R. V., Jensen, R. A. C., and Papastavrou, V. A. (1993). Marine Fauna of Oman, Cetaceans, Turtles, Seabirds and Shallow Water Corals. A Marine Conservation and Development Report. Gland: IUCN, 1-61.

Schofield, G., Dimadi, A., Fossette, S., Katselidis, K. A., Koutsoubas, D., Lilley, M. K. S., et al. (2013). Satellite tracking large numbers of individuals to infer population level dispersal and core areas for the protection of an endangered species. Divers. Distrib. 19, 834-844. doi: 10.1111/ddi.12077

Schofield, G., Hobson, V. J., Fossette, S., Lilley, M. K. S., Katselidis, K. A., and Hays, G. C. (2010). Fidelity to foraging sites, consistency of migration routes and habitat modulation of home range by sea turtles. Divers. Distrib. 16, 840-853. doi: 10.1111/j.1472-4642.2010.00694.x

Scott, P., Hodgson, D. J., Witt, M. J., Coyne, M. S., Adnyana, W., Blumenthal, J. M., et al. (2012). Global analysis of satellite tracking data shows that adult green turtles are significantly aggregated in Marine Protected Areas. Glob. Ecol. Biogeogr. 21, 1035-1061.

Serrano, O., Almahasheer, H., Duarte, C. M., and Irigoien, X. (2018). Carbon stocks and accumulation rates in Red Sea seagrass meadows. Sci. Rep. 8:15037. doi: 10.1038/s41598-018-33182-8)

Shepherd, A. R. D. (2015). Project Draft Final Report Review of Legislation, Strategies, Policies and Management Plans for Fisheries Sectors in the PERSGA Countries of Djibouti, Jordan, Saudi Arabia, Sudan and Yemen: A Regional Synthesis. Jeddah: PERSGA, 1-62.

Shimada, T., Duarte, C. M., Al-Suwailem, A. M., Tanabe, L. K., and Meekan, M. G. (2021a). Satellite tracking reveals nesting patterns, site fidelity, and potential impacts of warming on major green turtle rookeries in the Red Sea. Front. Mar. Sci. 8:633814. doi: 10.3389/fmars.2021.633814

Shimada, T., Jones, R., Limpus, C., Groom, R., and Hamann, M. (2016). Longterm and seasonal patterns of sea turtle home ranges in warm coastal foraging habitats: implications for conservation. Mar. Ecol. Prog. Ser. 562, 163-179. doi: 10.3354/meps11972

Shimada, T., Limpus, C. L., Hamann, M., Bell, I., Esteban, N., Groom, R., et al. (2020). Fidelity to foraging sites after long migrations. J. Anim. Ecol. 89, 1008-1016.

Shimada, T., Meekan, M. G., Baldwin, R., Al-Suwailem, A. M., Clarke, C., Santillan, A. S., et al. (2021b). Distribution and temporal trends in the abundance of 
nesting sea turtles in the Red Sea. Biol. Conserv. 261:109235. doi: 10.1016/j. biocon.2021.109235

Stokes, H. J., Mortimer, J. A., Hays, G. C., Unsworth, R. K. F., Laloë, J.-O., and Esteban, N. (2019). Green turtle diet is dominated by seagrass in the Western Indian Ocean except amongst gravid females. Mar. Biol. 166, 1-12. doi: 10. 1007/s00227-019-3584-3

Stokes, K. L., Broderick, A. C., Canbolat, A. F., Candan, O., Fuller, W. J., Glen, F., et al. (2015). Migratory corridors and foraging hotspots: critical habitats identified for Mediterranean green turtles. Divers. Distrib. 21, 665-674. doi: 10.1111/ddi.12317

Tamario, C., Sunde, J., Petersson, E., Tibblin, P., and Forsman, A. (2019). Ecological and evolutionary consequences of environmental change and management actions for migrating fish. Front. Ecol. Evol. 7:271. doi: 10.3389/fevo.2019. 00271

Tanabe, L. K., Ellis, J., Elsadec, I., and Berumen, M. L. (2020). Potential feminization of Red Sea turtle hatchlings as indicated by in situ sand temperature profiles. Conserv. Sci. Pract. 2020:e266. doi: 10.1111/csp 2.266

Teclemariam, Y., Giotom, M., Mengstu, T., Abraha, H., and Mahmud, S. (2009). An update on marine turtles in Eritrea, Red Sea. Indian Ocean Turtle Newsl. 9, 6-10.

Tesfamichael, D., and Pauly, D. (2016). "Introduction," in The Red Sea Ecosystem and Fisheries. Coral Reefs of the World, Vol. 7, eds D. Tesfamichael and D. Pauly (Berlin: Springer), 1-19. doi: 10.1093/actrade/9780198837572.003. 0005
Troëng, S., Evans, D. R., Harrison, E., and Lagueux, C. J. (2005). Migration of green turtles Chelonia mydas from Tortuguero, Costa Rica. Mar. Biol. 148, 435-447. doi: 10.1007/s00227-005-0076-4

Wallace, B. P., Kot, C. Y., DiMatteo, A. D., Lee, T., Crowder, L. B., and Lewison, R. L. (2013). Impacts of fisheries bycatch on marine turtle populations worldwide: toward conservation and research priorities. Ecosphere 4:40. doi: 10.1890/ES12-00388.1

Conflict of Interest: The authors declare that the research was conducted in the absence of any commercial or financial relationships that could be construed as a potential conflict of interest.

Publisher's Note: All claims expressed in this article are solely those of the authors and do not necessarily represent those of their affiliated organizations, or those of the publisher, the editors and the reviewers. Any product that may be evaluated in this article, or claim that may be made by its manufacturer, is not guaranteed or endorsed by the publisher.

Copyright (C) 2021 Al-Mansi, Sambas, Abukaboos, Al Zahrani, Abdulaziz, Almasabi, Alkreda and Miller. This is an open-access article distributed under the terms of the Creative Commons Attribution License (CC BY). The use, distribution or reproduction in other forums is permitted, provided the original author(s) and the copyright owner(s) are credited and that the original publication in this journal is cited, in accordance with accepted academic practice. No use, distribution or reproduction is permitted which does not comply with these terms. 